\title{
1 Sex differences in innate anti-viral immune responses to respiratory
} viruses

3

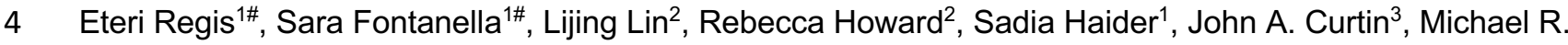

$5 \quad$ Edwards $^{1}$, Magnus Rattray ${ }^{2}$, Angela Simpson $^{3}$, Adnan Custovic $^{1} \dagger$, Sebastian L. Johnston ${ }^{1 *} \dagger$

${ }^{1}$ National Heart and Lung Institute, Imperial College London, United Kingdom

${ }^{2}$ Faculty of Biology, Medicine and Health, University of Manchester, M13 9PT, UK

${ }^{3}$ Division of Infection, Immunity and Respiratory Medicine, Faculty of Biology, Medicine and Health,

Manchester Academic Health Sciences Centre, University of Manchester and University Hospital of South Manchester NHS Foundation Trust, Manchester, UK

\section{*To whom correspondence should be addressed: Sebastian L Johnston, Professor of Respiratory} Medicine \& Allergy, National Heart and Lung Institute, Imperial College London, Norfolk Place, London W2 1PG, United Kingdom; Tel: +44 207594 3764, e-mail: s.johnston@imperial.ac.uk

Classification: Biological sciences; Immunology and Inflammation.

Key words: mortality, respiratory virus, COVID-19, gender, innate immunity, interferons

\section{Author Contributions:}

\#Eteri Regis and Sara Fontanella contributed equally to this article

†Adnan Custovic and Sebastian Johnston contributed equally to this article 
medRxiv preprint doi: https://doi.org/10.1101/2020.09.18.20195784; this version posted September 18, 2020. The copyright holder for this preprint (which was not certified by peer review) is the author/funder, who has granted medRxiv a license to display the preprint in perpetuity.

It is made available under a CC-BY-NC-ND 4.0 International license .

\section{Abstract}

26

27

28

29

30

31

32

33

34

35

36

37

38

39

40

41

42

43

Males have excess morbidity and mortality from respiratory viral infections and especially so in COVID-

19. The mechanisms explaining this excess in disease burden in males are unknown. Innate immune responses are likely critical in protection against a novel virus like SARS-CoV-2. We hypothesised that innate immune responses may be deficient in males relative to females. To test this we stimulated peripheral blood mononuclear cells (PBMCs) from participants in a population-based birth cohort with three respiratory viruses (rhinoviruses-RV-A16 and RV-A1, and respiratory syncytial virus-RSV) and two viral mimics (R848 and CpG-A, to mimic responses to SARS-CoV-2). We measured interferon (IFN) and IFN-induced chemokine responses and investigated sex differences in virus-induced responses. IFN- $\alpha$, IFN- $\beta$ and IFN- $\gamma$ responses to RV-A16 were deficient in males compared to females, fold-inductions being 1.92-fold $(P<0.001), 2.04$-fold $(P<0.001)$ and 1.77 -fold $(P=0.003)$ lower in males than females, respectively. Similar significant deficiencies in innate immune responses were observed in males for eleven other cytokine-stimulus pairs. Responses in males were greater than those in females in only one of 35 cytokine-stimulus pairs investigated. Review of healthcare records revealed that $12.1 \%$ of males but only $6.6 \%$ of females were admitted to hospital with respiratory infections in the first year of life $(P=0.017)$. Impaired innate anti-viral immunity in males likely results in high morbidity and mortality from respiratory viruses including COVID-19. Males may preferentially benefit from therapies that boost innate anti-viral immune responses. 
medRxiv preprint doi: https://doi.org/10.1101/2020.09.18.20195784; this version posted September 18, 2020. The copyright holder for this preprint (which was not certified by peer review) is the author/funder, who has granted medRxiv a license to display the preprint in perpetuity. It is made available under a CC-BY-NC-ND 4.0 International license .

\section{Significance Statement}

45 Clinical outcomes including, mortality, Intensive care unit admissions and hospital admissions, during 46 COVID-19 disease are consistently and substantially worse in males than in females. The mechanisms 47 underlying this increased susceptibility to severe disease in males are not understood. We hypothesised

48 that the differential outcomes between sexes could be a consequence of deficient innate interferon 49 responses in males, and more robust innate interferon responses in females. We have investigated such 50 responses in a large population-based cohort and found that indeed males have deficient innate interferon 51 responses to viral stimuli, including stimuli that mimic SARS-CoV-2 infection, relative to females. Our

52 findings have very important treatment implications as interferons are available for clinical use with 53 immediate effect. 
medRxiv preprint doi: https://doi.org/10.1101/2020.09.18.20195784; this version posted September 18, 2020. The copyright holder for this

preprint (which was not certified by peer review) is the author/funder, who has granted medRxiv a license to display the preprint in perpetuity.

It is made available under a CC-BY-NC-ND 4.0 International license .

55

56

57

58

59

60

61

62

63

64

65

66

67

68

69

70

71

72

73

74

75

76

77

78

79

80

81

\section{Introduction}

Respiratory viral infections are a leading cause of ill health and mortality(1). This has been highlighted by the immense global impact of COVID-19(2) and the enormous public health threat it poses. Males and females differ in the prevalence and severity of viral infections(3). In COVID-19, risk factors for mortality include older age, the presence of comorbid conditions, and male sex $(4,5)$. In an early report of 191 cases from Wuhan, China, $70 \%$ of deaths were male, while only $30 \%$ were female(5). This gender imbalance has subsequently been confirmed in a large study of 44,672 COVID-19 confirmed cases in China, where $63.8 \%$ of deaths were male while only $36.2 \%$ were female, and the case fatality rate for males was $2.8 \%$, while that for females was $1.7 \%(6)$. Similar mortality data are reported in Italy where 9390 of $13,334(70.4 \%)$ of COVID-19 deaths in persons under 90 years of age reported by $6^{\text {th }}$ April 2020 were male, and 3,944 (29.6\%) were female(7). In the UK, the data are very similar, with males representing $65 \%$ of deaths involving COVID-19 reported by $27^{\text {th }}$ March 2020 , while $35 \%$ were females(8). Intensive Care Unit (ICU) admission are also much higher for males in Lombardy, Italy, where $82 \%$ of 1591 ICU admissions were male(9). The ICU data are very similar in the UK, as $72.5 \%$ of 3883 confirmed COVID-19 cases admitted to ICU by the $10^{\text {th }}$ April 2020 were male, and $27.5 \%$ female(10). A recent large UK study of 20,133 patients admitted to hospital with COVID-19, reported more men were admitted than women (men $60 \%, n=12$ 068; women $40 \%, n=8065)(11)$. An even larger study of primary care records of $17,278,392$ adults linked to 10,926 COVID-19-related deaths reported COVID-19-related death was associated with: being male with a hazard ratio of 1.59(12). COVID-19 case identification in population screening also reports a male preponderance, with more males than females testing positive in both targeted testing (16.7\% vs $11.0 \%)$ and in population screening $(0.9 \%$ vs $0.6 \%)(13)$.

The mechanisms explaining excess COVID-19 mortality, ICU and hospital admissions and case identification in males are unknown(14). Understanding how sexes differ in their responses to respiratory viruses is critically important for the development of treatment and preventative strategies, which may differ for males and females. Innate immune responses, mediated by anti-viral interferon (IFN) production by virus-infected cells will be critical in protection against SARS-CoV-2, a new virus that humans have never previously encountered. We have previously reported that deficient IFN- $\alpha(15), \operatorname{IFN}-\beta(15,16)$ and 
medRxiv preprint doi: https://doi.org/10.1101/2020.09.18.20195784; this version posted September 18, 2020. The copyright holder for this preprint (which was not certified by peer review) is the author/funder, who has granted medRxiv a license to display the preprint in perpetuity. It is made available under a CC-BY-NC-ND 4.0 International license.

82 IFN- $\gamma(17,18)$ production by virus-infected cells from people with asthma is implicated in their increased 83 susceptibility to respiratory virus infections(19). However, little is known about the variation within the 84 human immune system in relation to the patterns of response to viruses at a population level. We

85 hypothesised that the adverse outcomes for males reported in COVID-19 may be related to deficient 86 innate immune responses to viruses in males relative to females. To investigate this, we stimulated 87 peripheral blood mononuclear cells (PBMCs) from male and female participants in a population-based 88 birth cohort with three common respiratory viruses and two viral mimics (R848 and CpG-A, to mimic responses to SARS-CoV-2) and measured IFN and IFN-induced chemokine responses in supernatants.

90 
medRxiv preprint doi: https://doi.org/10.1101/2020.09.18.20195784; this version posted September 18, 2020. The copyright holder for this

preprint (which was not certified by peer review) is the author/funder, who has granted medRxiv a license to display the preprint in perpetuity.

It is made available under a CC-BY-NC-ND 4.0 International license .

100

101

\section{Results}

\section{Participant flow and demographic data}

Of 751 participants who attended follow-up at age 16 years, 361 provided blood samples. After quality control (Supplementary Appendix), we excluded data for 16 participants. Participant flow is presented in Fig. 1. There were no differences in demographic characteristics, environmental exposures and clinical features between participants included in this analysis $(n=345)$ and those who were not $(n=406)$, either in the whole population or stratified by sex (Table S1).

The demographic and clinical characteristics of the 345 subjects included in this analysis are shown in Table 1. There were no significant differences between sexes in birth weight, relevant environmental exposures (including position in sibship, pet ownership and tobacco smoke exposure) or common respiratory diseases, such as wheezing and asthma. No significant differences were observed in cell viability between sexes (Fig. S1).

\section{Induction of IFNs and IFN-induced chemokines in PBMCs in response to viral stimuli}

There was a significant induction of all IFNs and IFN-induced chemokines in response to all viral stimuli compared to medium control (Figures 2 and S2). Cytokine responses to viral stimuli were not normally distributed (Shapiro-Wilk test, Table S2). The most potent inducers of IFN- $\alpha$ were CpG-A, RSV and RVA16, with median concentrations of $184.7 \mathrm{pg} / \mathrm{mL}, 108.3 \mathrm{pg} / \mathrm{mL}$ and $34.0 \mathrm{pg} / \mathrm{mL}$ respectively compared to $0.0 \mathrm{pg} / \mathrm{mL}$ in medium control (all $P<0.001$, Figure 2). RV-A1 and R848 also induced IFN- $\alpha$, but to lesser degrees (Fig. 2). Induction of IFN- $\beta$ followed a very similar pattern to that of IFN- $\alpha$, but with lower concentrations.

The most potent inducers of IFN- $y$ were R848, RV-A16 and RSV, with median concentrations of 102.1pg/mL, $60.7 \mathrm{pg} / \mathrm{mL}$ and $35.7 \mathrm{pg} / \mathrm{mL}$, respectively, compared to $0.2 \mathrm{pg} / \mathrm{mL}$ in medium control (all $P<0.001$, Figure 2). RV-A1 and CpG-A also induced IFN-y, but to lesser degrees (Fig. 2).

The most potent inducers of the IFN-induced chemokine CXCL10/IP-10, were RV-A16, RSV and CpG-A, with median concentrations of $1841.0 \mathrm{pg} / \mathrm{mL}, 1515.2 \mathrm{pg} / \mathrm{mL}$ and $1343.4 \mathrm{pg} / \mathrm{mL}$ respectively, compared to 
medRxiv preprint doi: https://doi.org/10.1101/2020.09.18.20195784; this version posted September 18, 2020. The copyright holder for this preprint (which was not certified by peer review) is the author/funder, who has granted medRxiv a license to display the preprint in perpetuity.

It is made available under a CC-BY-NC-ND 4.0 International license .

116

117

118

119

120

121

122

123

124

125

126

127

128

129

130

131

132

133

134

135

136

137

138

139

140

141

130.6pg/mL in medium control samples (all $P<0.001$, Figure 2). RV-A1 and R848 also induced CXCL10/IP-10, but to lesser degrees.

The IFN-induced chemokines CCL2/MCP1, CCL4/MIP-1 $\beta$ and CCL13/MCP4 were also all induced by all viral stimuli, CCL2/MCP1 and CCL4/MIP-1 $\beta$ most potently by R848 and CCL13/MCP4 most potently by RV-A1 (Fig. S2).

\section{Differences between males and females in IFN and IFN-induced chemokine induction}

Results of the comparisons between sexes are presented in Table 2. The trend across all viral stimuli and responses was remarkably consistent, as almost all of the IFNs and IFN-induced chemokines had higher levels of induction in females compared to males: out of 35 stimulus-cytokine pairs, females exhibited higher induction than males in 32 cases (Table 2).

The induction of IFN- $\alpha$ was significantly higher in females than in males for all five viral stimuli (with $P$ values ranging from $<0.001$ to 0.018 , Table 2 ). After adjustment for multiple testing, these differences remained statistically significant for RV-A16, RV-A1 and R848 ( $P=0.001,0.041$ and 0.002 respectively), and marginal for RSV and CpG-A ( $P=0.055$ and 0.051 respectively, Table 2$)$. The magnitude of the differences observed for IFN- $\alpha$ ranged from a 1.34-fold (34\%) greater induction of IFN- $\alpha$ in females than in males for RSV, to a 2.06-fold (106\%) greater induction for R848.

The individual responses of each IFN and of CXCL10/IP-10 to RV-A16 stimulation are depicted in Fig. 3 A-D, with induction in females significantly greater than that in males for IFN- $\alpha$ at 1.92 -fold (92\%) greater $(P<0.001)$, IFN- $\beta$ at 2.04 -fold (104\%) greater $(P<0.001)$, IFN- $\gamma 1.77$-fold $(77 \%)(P=0.003)$ and CXCL10/IP101.40 -fold $(40 \%)$ greater $(P=0.01)$.

Regarding the viral mimics R848 and CpG-A (which mimic responses to SARS-CoV-2 infection), females had significantly greater induction of IFN- $\alpha$ in response to R848 stimulation (2.06-fold, $P<0.001$ ), and in response to CpG-A (1.71-fold, $P=0.015)$ (Fig. $4 \mathrm{~A}-\mathrm{B}$ ), though the latter difference was marginal after adjustment $(P=0.051$, Table 2$)$. Females also had significantly greater induction of IFN- $\gamma(2.01$-fold, $P=0.003)$ and $C C L 13 / M C P 4$ (1.36-fold, $P=0.04)$ in response to CpG-A than males (Fig. 4 C-D), though the latter difference was marginal after adjustment $(P=0.10$, Table 2$)$. 
medRxiv preprint doi: https://doi.org/10.1101/2020.09.18.20195784; this version posted September 18, 2020. The copyright holder for this preprint (which was not certified by peer review) is the author/funder, who has granted medRxiv a license to display the preprint in perpetuity.

It is made available under a CC-BY-NC-ND 4.0 International license .

142

143

144

145

146

147

148

149

150

151

152

153

154

155

156

157

158

159

160

161

162

163

164

165

166

167

Stimulation with RV-A1 also resulted in significantly greater induction in females than in males for IFN- $\alpha$ (Fig. S3A, 1.55-fold, $P=0.011$ ), CXCL10/IP-10 (Figure S3B, 1.23-fold, $P=0.041$, though this difference was marginal after adjustment $[P=0.10$, Table 2]), CCL4/MIP-1 $\beta$ (Fig. S3C, 1.16-fold, $P=0.01$ ) and CCL13/MCP4 (Fig. S3D, 1.61-fold, $P=0.002$ ), as did stimulation with RSV (Fig. S3 E-F) for IFN- $\alpha$ $(P=0.018)$ and CCL13/MCP4 $(P=0.019)$. These latter two differences were marginal after adjustment (both $P=0.055$, Table 2).

Since adverse clinical outcomes in viral infections are likely in those individuals with the weakest innate anti-viral responses, we examined proportions of males and females whose innate anti-viral responses were below certain lower thresholds. We restricted this analysis to IFN- $\alpha$ and low thresholds were defined as the $15^{\text {th }}, 20^{\text {th }}$ and $25^{\text {th }}$ percentile of the response determined from the entire population. Results are shown in Fig. 5 and S4. Proportions of males having IFN- $\alpha$ responses to RV-A16, RSV and R848 below each threshold were significantly higher compared to the proportion of females (Fig. 5). Similar trends were observed for response of IFN- $\alpha$ to RV-A1, and CpG-A (Fig. S4), but these did not reach statistical significance.

\section{Differences in early-life severe LRTIs between males and females}

Having observed diminished innate immune responses to viral stimuli in males, and greater proportions of males with weak innate immune responses, we investigated whether frequencies of early-life LRTIs were also different between sexes in our cohort. We focussed on early life, as this is when innate immune responses will be most important, as the very young will have had little opportunity to develop memory responses. Results are presented in Table S3. Among participants attending follow up at age 16 years who had primary care records available for inspection ( $n=651), 12.1 \%$ of males and $6.6 \%$ of females were admitted to hospital with LRTI in the first year of life $(P=0.017)$. In the second year of life, $6.1 \%$ of males but only $0.75 \%$ of females were admitted to hospital with LRTI $(P<0.001)$. We observed a similar trend for RSV-positive bronchiolitis, with $4.32 \%$ of males hospitalised, compared to $1.64 \%$ of females, but the difference between the sexes did not reach formal statistical significance $(P=0.067)$. 
medRxiv preprint doi: https://doi.org/10.1101/2020.09.18.20195784; this version posted September 18, 2020. The copyright holder for this preprint (which was not certified by peer review) is the author/funder, who has granted medRxiv a license to display the preprint in perpetuity.

It is made available under a CC-BY-NC-ND 4.0 International license .

168

169

170

171

172

173

174

175

176

177

178

179

180

181

182

183

184

185

186

187

188

189

190

191

192

193

194

\section{Discussion}

We hypothesised that the adverse outcomes for males reported in virus infections and especially in SARS-CoV-2 infections, including substantially increased COVID-19-related mortality, ICU admissions, hospital admissions and case identification, may be related to deficient innate immune responses in males relative to females, resulting in increased disease severity in males. Our analysis of induction of three IFNs and four IFN-induced chemokines by five respiratory viruses/viral stimuli in PBMCs sampled from participants in a population-based birth cohort study demonstrated that responses in females were substantially greater than those in males in 32 of 35 cytokine-stimulus pairs. Of these, differences in 14 cytokine-stimulus pairs were statistically significant, of which 9 remained significant after adjustment for multiple testing, all showing increased responses in females. These statistically significant cytokinestimulus pairs included IFN- $\alpha$ induction in response to each viral stimulus, IFN- $\beta$ induction in response to RV-A16 and IFN-y induction in response to RV-A16 and CpG-A.

IFN- $\alpha$ and IFN- $\beta$ are type I IFNs that are critical mediators of innate anti-viral immune responses, inducing apoptosis of virus-infected cells and inducing over 300 IFN-stimulated genes, many of which have a variety of direct anti-viral activities(20). Through these combined activities, type I IFNs can abort virus replication in virus-infected cells(16).

IFN-y is the only type II IFN, and it also is very important in promoting innate immune responses principally by activating natural killer (NK) cells which are important in innate immune defense against virus infections, by rapid killing of virus-infected cells(21). IFN-y also primes other immune cells such as macrophages, to release anti-viral cytokines(22) and to phagocytose infected cells(21). IFN-y has been shown to suppress mouse coronavirus replication, though this was dependent, in part, on induction of type I IFN secretion(23).

Type I and II IFNs also cooperate and work together to activate macrophages, NK cells, dendritic cells and $\mathrm{T}$ cells by enhancing cell activation, antigen presentation, cell trafficking, cell differentiation and proliferation, resulting in markedly enhanced innate and acquired antiviral immune effector function(24). Thus, deficiency in either or both of these IFN types would be expected to markedly increase severity of virus-induced illnesses. We have previously described deficiency in IFN- $\alpha(15)$, IFN- $\beta(15,16)$ and IFN- 
medRxiv preprint doi: https://doi.org/10.1101/2020.09.18.20195784; this version posted September 18, 2020. The copyright holder for this preprint (which was not certified by peer review) is the author/funder, who has granted medRxiv a license to display the preprint in perpetuity.

It is made available under a CC-BY-NC-ND 4.0 International license .

$195 \mathrm{Y}(17,18)$ in patients with asthma and have reported that patients with asthma have increased

196

197

198

199

200

201

202

203

204

205

206

207

208

209

210

211

212

213

214

215

216

217

218

219

220 susceptibility to respiratory virus infections(19). In addition, recent reports indicate that deficiencies in IFN responses are linked to increased susceptibility to virus-induced exacerbations of chronic obstructive pulmonary disease(25-28). These data therefore support the biological and clinical relevance of our findings.

The deficiencies we observed in IFN responses in males are reflected in a significantly increased incidence of severe LRTIs requiring hospital admissions in the first and second years of life, as well as with a trend for increased incidence of RSV-proven bronchiolitis, a disease with a peak incidence at 4.5 months of age(29). We focused on severe LRTIs requiring hospital admissions in early life, as these are almost exclusively viral in aetiology. The first 2 years of life is a time of life during which innate immune responses will be most important, as infants and toddlers will have had very little experience of viral RTIs and will therefore have little memory/acquired immunity. The fact that we find females produce approximately twice the concentrations of IFN- $\alpha$ and IFN- $\beta$ in response to RV-A16 and of IFN- $\alpha$ in response to R848, 55\% more IFN- $\alpha$ in response to RV-A1 and $71 \%$ and $52 \%$ more IFN- $\alpha$ and IFN- $\beta$ in response to $\mathrm{CpG}-\mathrm{A}$, than do males, and females have $\sim$ half the number of LRTIs requiring hospital admission in the first year of life, $88 \%$ fewer in the second year of life and $62 \%$ fewer admissions with RSV-positive bronchiolitis also lends credence to the biological and clinical relevance of our findings in relation to diseases where innate immune responses will be vitally important in protection against adverse outcomes.

SARS-CoV-2 is a virus completely new to mankind, it is therefore even more important to have as strong an innate immune response to this virus as possible, to reduce the likelihood of adverse outcomes. The marked reductions in type I IFN responses to viral stimuli reported herein in males relative to females, with the relationships discussed above with virus-induced exacerbations of lung disease $(15-18,25-28)$, and with severe viral LRTIs in infants in our cohort, make it almost certain that the deficient IFN responses we report in males will be at least in part responsible for the adverse outcomes to SARS-CoV2 infection currently being reported in COVID-19 in males(2, 4-10, 12, 13). 
medRxiv preprint doi: https://doi.org/10.1101/2020.09.18.20195784; this version posted September 18, 2020. The copyright holder for this preprint (which was not certified by peer review) is the author/funder, who has granted medRxiv a license to display the preprint in perpetuity.

It is made available under a CC-BY-NC-ND 4.0 International license .

221 A very recent study by Takahashi et al studied sex differences in immune responses during COVID-19

222 disease in hospitalised patients and claimed that these differences underlie sex differences in COVID-19

223 disease outcomes(30). This study reported female patients mounted significantly more robust $\mathrm{T}$ cell

224 activation than male patients during SARS-CoV-2 infection. They also found that a poor T cell response

225 was associated with worse disease outcome in male patients. This study also reported significantly

226 increased plasma concentrations of IL-8 and IL-18 and numbers of peripheral blood non-classical

227 monocytes in males, with trends to increased SARS-CoV-2 virus load (of magnitude 1-2 Log $10 \mathrm{copies} / \mathrm{mL}$,

228 noting that virus load was only measured in the upper respiratory tract and not in the lung) and plasma

229 CXCL-10 concentrations in males. As robust innate interferon responses are well known to drive robust T

230 cell responses during viral infections(24), and deficient innate interferon responses studied ex vivo pre-

231 infection are known to relate to increased virus load, increased inflammatory outcomes and worse clinical

232 outcomes upon subsequent in vivo respiratory virus infection(31), we suggest all the differential outcomes

233 between sexes identified by Takahashi et al would be a consequence of the deficient innate interferon

234 responses in males, and more robust innate interferon responses in females, that we report herein.

235 Our study has strengths and limitations. Strengths include the population-based cohort design, so our

236 participants should be representative of the general population, the fact that illness ascertainment was

237 carried out by personal inspection of primary care records to maximise accuracy, that PBMCs were

238 stimulated/infected with the most common respiratory viruses and with ligands of TLRs that are

239 representative of RNA respiratory viruses such as SARS-CoV-2, and that infections/stimulations were

240 carried out using a single batch of each virus/stimulus and conducted by a single highly experienced

241 individual, so any variability in response will be participant-related and not a result of technical variability.

242 Limitations include that PBMCs were not directly infected/stimulated with SARS-CoV-2. This was not

243 possible as our participants' PBMCs were infected/stimulated before SARS-CoV-2 existed as a human

244 pathogen. However, we did study ligands (R848 and CpG-A) to the endosomal expressed TLRs 7/8/9,

245 which are clearly engaged by positive strand RNA viruses such SARS-CoV-2, which require endosomal

246 processing as part of viral entry into cells(32). Furthermore, consistency of findings across all viral stimuli

247 and responses suggests that our findings should apply to all respiratory viruses including SARS-CoV-2. 
It is made available under a CC-BY-NC-ND 4.0 International license .

248

249

250

251

252

253

254

255

256

257

258

259

260

261

262

263

264

265

266

267

268

269

270

271

272

273

274

We were not able to assess the importance of induction of the type III IFNs, IFN- $\lambda$ s $1-3$, which are very important in innate antiviral responses against respiratory viruses(31, 33-35), as the type III IFNs were not significantly induced by any infection/stimulus in the PBMCs that we studied (data available on request).

This is likely because respiratory epithelial cells are the main source of type III IFNs, and the cells within PBMCs that are capable of producing type III IFNs when studied fresh(35) likely succumbed as a result of freeze/thawing.

Our findings have important therapeutic implications. IFN- $\alpha$ and IFN- $\beta$ have both been shown to inhibit replication of SARS-CoV-2(36, 37). A very recent report indicates that early subcutaneous IFN- $\beta$ administered up to three times weekly (with ribavirin) in the first seven days after diagnosis of COVID-19 was associated with faster virus clearance and clinical improvement and with shorter hospital stays(38). It is likely that most of this clinical benefit resulted from IFN- $\beta$ rather than ribavirin(39), but ongoing clinical trials (more than 20 trials investigating IFN- $\alpha$ or IFN- $\beta$ in COVID-19 are currently registered on clinical trial registries) will determine whether and to what degree type I IFN therapies are effective.

Since IFN production by virus-infected respiratory cells is likely critical to innate anti-viral immunity against SARS-CoV, therapeutic use of agents that boost innate IFN induction by virus infections may be efficacious in treatment of COVID-19. We reported 10 years ago that azithromycin doubles IFN- $\beta$ and IFN- $\lambda$ production from virus-infected human bronchial epithelial cells in vitro(40). Erythromycin and telithromycin did not(40). Innate IFN-induction by azithromycin in virus-infected human lung cells has been confirmed in three subsequent studies(41-43), one of which confirmed this property was variable among 225 novel macrolides studied, as some macrolides induced innate IFNs (up to $\sim 5$-fold), while others did not(43). Thus this innate IFN-inducing property is not a property of all macrolides, but is reproducibly a property of azithromycin(40-43). This is supported by a recent report that among 1,520 clinically approved compounds from a chemical library screened for anti-viral activity against SARS-CoV2, only two had clear dose-responsive replication-inhibition curves with identified $\mathrm{EC}_{50}$ concentrations in the $1-10 \mu \mathrm{M}$ range. These two compounds were azithromycin and hydroxychloroquine, and they also had EC 90 concentrations of $\sim 10 \mu \mathrm{M}$ and $\sim 15 \mu \mathrm{M}$ respectively, with azithromycin achieving $\sim 100 \%$ inhibition of SARS-CoV-2 replication at $\sim 15 \mu \mathrm{M}(44)$. Azithromycin treatment of COVID-19 patients (especially early in 
275 the disease course when patients progress from mild to moderate disease severity) in order to boost IFN

276

277

278

279

280

281

282

283

284

285

286

287

288

289

290

291

292

293

294

295

296

297

298

299

300 production by respiratory epithelial cells when infected with SARS-CoV-2, may therefore be effective, especially in males who demonstrably have deficient innate IFN responses when compared to females.

This deduction is indirectly supported by high-quality randomised, double-blind, placebo-controlled clinical trial evidence that azithromycin is effective in preventing progression to severe lower respiratory tract illnesses (which are initiated by viral infections) in preschool children(45) and in prevention of asthma exacerbations (the great majority of which are caused by respiratory viruses) in uncontrolled moderate/severe asthma(46). Ongoing studies (more than 50 clinical trials investigating azithromycin in COVID-19 are currently on trial registries) will determine the effectiveness of azithromycin, and we would suggest that post-hoc analyses include stratification by sex.

Our findings have important implications for prevention strategies, which are best implemented when high-risk populations can be identified. Respiratory viruses, including SARS-CoV-2, are initially encountered by the nasal epithelium where infection is initiated. An adequate anti-viral response can contain the virus in the upper airway, with cold-like symptoms, and a diminished response can see the infection spreading to the lower airways to induce severe LRTI. Our data support a preventive strategy, particularly among males, which involves targeting the innate immune system with 'immune training' agents to boost resistance to primary infection with SARS-CoV-2 and enhance the capacity to control the intensity of airways' inflammatory responses (such as, for example, OM-85(47), which has been shown to effectively and safely reduce winter hospitalizations in $\operatorname{COPD}(48)$, severe bronchitis among residents in care-homes for elderly(49), and LRTIs in children(50)). Effective prophylactic therapy will be crucially important while we wait for a vaccine.

Our findings also have important implications for a hotly debated topic, namely whether "man flu" actually exists or not(51). Here we provide a biological basis to explain why males would be expected to suffer more than females when infected by respiratory viruses.

In conclusion, high morbidity and mortality from respiratory viruses including COVID-19 in males is likely explained by impaired innate anti-viral immune in males compared to females. Males may preferentially 
medRxiv preprint doi: https://doi.org/10.1101/2020.09.18.20195784; this version posted September 18, 2020. The copyright holder for this preprint (which was not certified by peer review) is the author/funder, who has granted medRxiv a license to display the preprint in perpetuity.

It is made available under a CC-BY-NC-ND 4.0 International license .

301 benefit from therapies that boost innate anti-viral immune responses to viruses, both for treatment and 302 prevention. 
medRxiv preprint doi: https://doi.org/10.1101/2020.09.18.20195784; this version posted September 18, 2020. The copyright holder for this preprint (which was not certified by peer review) is the author/funder, who has granted medRxiv a license to display the preprint in perpetuity.

It is made available under a CC-BY-NC-ND 4.0 International license .

303

304

305

306

307

308

309

310

311

312

313

314

315

316

317

318

319

320

321

322

323

324

325

326

327

\section{Materials and Methods}

Detailed methods are presented in the Supplementary Appendix.

\section{Study design, setting, participants and data sources}

The study subjects were participants in the Manchester Asthma and Allergy Study, a population-based birth cohort study(52). The study was approved by the research ethics committee; we obtained written informed consent. PBMCs were collected from subjects at age 16 years and cryopreserved. We used male or female sex as assigned at birth.

\section{Cell stimulations and cytokine measurement}

The PBMCs were thawed on the day of stimulation, counted and had viability checked as described(53, 54). Cells were distributed in 96 -well round bottom plates at $2 * 10^{5}$ cells/well and were stimulated with two rhinoviruses (RVs), RV-A16 and RV-A1, and respiratory syncytial virus (RSV). We also used two viral mimics (which mimic infection with SARS-CoV-2), the Toll-like receptor (TLR)-7/8 ligand resiquimod (R848) and the TLR-9 ligand class A CpG oligonucleotide (CpG-A), both at $1 \mu \mathrm{M}$ concentrations (Invivogen). Concentrations of IFN- $\alpha$, IFN- $\beta$, IFN- $\gamma$ and four IFN-induced chemokines CXCL10/IP-10, CCL2/MCP1, CCL4/MIP-1 $\beta$ and CCL13/MCP4 were measured in supernatants $24 \mathrm{~h}$ post-stimulation, using the Meso Scale Discovery ${ }^{\circledR}$ kits as previously described $(53,54)$.

\section{Clinical outcomes: Lower respiratory tract infections (LRTI)}

We extracted data on severe LRTIs requiring hospital admissions in the first and second year of life from electronic and paper-based primary care medical records; age in days at the time of each event was documented to provide an accurate account of each episode(54).

\section{Statistical analysis}

Quality control: Prior to analyses, data were pre-processed according to the pipeline described in our previous study(53), to exclude samples with low viability and/or no response of any cytokine to any stimulus. Analysis: We expressed the induction of IFNs and IFN-induced chemokines as raw values (in $\mathrm{pg} / \mathrm{mL}$ ) and fold-induction over medium controls. The data were summarised as median and interquartile range (IQR). 
medRxiv preprint doi: https://doi.org/10.1101/2020.09.18.20195784; this version posted September 18, 2020. The copyright holder for this preprint (which was not certified by peer review) is the author/funder, who has granted medRxiv a license to display the preprint in perpetuity. It is made available under a CC-BY-NC-ND 4.0 International license.

328 Univariate comparisons between groups were performed using the Wilcoxon rank sum test (2-tailed).

329 Benjamini-Hochberg correction was applied to account for multiple testing(55). Proportions of males and

330 females with IFN responses to viral stimuli below the $15^{\text {th }}, 20^{\text {th }}$ and $25^{\text {th }}$ percentiles of the entire

331 population were compared using chi-squared tests. Associations with $P<0.05$ were considered significant.

332 Data availability

333 The data that support the findings of this study are available from the corresponding author upon

334 reasonable request.

335 
medRxiv preprint doi: https://doi.org/10.1101/2020.09.18.20195784; this version posted September 18, 2020. The copyright holder for this preprint (which was not certified by peer review) is the author/funder, who has granted medRxiv a license to display the preprint in perpetuity.

It is made available under a CC-BY-NC-ND 4.0 International license .

336

337

338

339

340

341

342

343

344

345

346

347

348

349

350

351

352

353

354

355

356

357

358

359

360

361

362

\section{Acknowledgments:}

Funding: MRC grants MR/L012693/1, MR/K002449/2 and MR/S025340/1. SLJ is the Asthma UK Clinical Chair (grant CH11SJ) and a National Institute of Health Research (NIHR) Emeritus Senior Investigator and is funded in part by European Research Council Advanced Grant 788575. This research was supported by the NIHR Imperial and Manchester Biomedical Research Centres (BRCs). The views expressed are those of the author(s) and not necessarily those of the NIHR or the Department of Health and Social Care.

Author contributions: All authors contributed to the writing of the manuscript and have approved the final version for publication. E.R., S.F., L.L., R.H., J.C., M.R. and M.E. performed the data analyses and E.R., S.F., graph and table production. E.R. performed all cell infections/stimulations and all cytokine measurements. S.H. performed primary care record inspection. A.S. coordinated the clinical study, A.C. and S.J. lead the study design, supervision and interpretation of the studies.

A.S., A.C. and S.J. are responsible for the overall content as guarantors. The guarantors accept full responsibility for the work, the conduct of the study, had access to the data, and controlled the decision to publish. The corresponding author attests that all listed authors meet authorship criteria and that no others meeting the criteria have been omitted.

Competing interests: Dr. Johnston reports personal fees from Virtus Respiratory Research, personal fees from Myelo Therapeutics $\mathrm{GmbH}$, personal fees from Concert Pharmaceuticals, personal fees from Bayer, personal fees from Synairgen, personal fees from Novartis, personal fees from Boehringer Ingelheim, personal fees from Chiesi, personal fees from Gerson Lehrman Group, personal fees from resTORbio, personal fees from Bioforce, personal fees from Materia Medical Holdings, personal fees from PrepBio Pharma, personal fees from Pulmotect, personal fees from Virion Health, personal fees from Lallemand Pharma, personal fees from AstraZeneca, outside the submitted work; In addition, Dr. Johnston has a patent Wark PA, Johnston SL, Holgate ST, Davies DE. Anti-virus therapy for respiratory diseases. UK patent application No. GB 0405634.7, 12 March 2004. with royalties paid, a patent Wark PA, Johnston SL, Holgate ST, Davies DE. Interferon-Beta for Anti-Virus Therapy for Respiratory Diseases. International Patent Application No. PCT/GB05/50031, 12 March 2004. with royalties paid, and 
medRxiv preprint doi: https://doi.org/10.1101/2020.09.18.20195784; this version posted September 18, 2020. The copyright holder for this preprint (which was not certified by peer review) is the author/funder, who has granted medRxiv a license to display the preprint in perpetuity. It is made available under a CC-BY-NC-ND 4.0 International license .

363 a patent Davies DE, Wark PA, Holgate ST, Johnston SL. Interferon Lambda therapy for the treatment of 364 respiratory disease. UK patent application No.6779645.9, granted 15th August 2012. licensed.

365 Dr. Custovic reports personal fees from Novartis, personal fees from Thermo Fisher Scientific, personal

366 fees from Philips, personal fees from Sanofi, personal fees from Stallergenes Greer, outside the

367 submitted work.

368 Dr. Simpson reports grants from MRC, grants from NIHR BRC, during the conduct of the study.

369 Dr. Curtin reports a patent with the University of California at San Francisco, unrelated to the submitted 370 work.

371 The rest of the authors declare that they have no relevant conflicts of interest. 


\section{References}

373 1. J. P. Mizgerd, Lung infection--a public health priority. PLoS Med 3, e76 (2006).

$3742 . \quad$ F. Wu et al., A new coronavirus associated with human respiratory disease in China. Nature 579, 375 265-269 (2020).

376 3. S. L. Klein, Sex influences immune responses to viruses, and efficacy of prophylaxis and treatments for viral diseases. Bioessays 34, 1050-1059 (2012).

4. X. Li et al., Risk factors for severity and mortality in adult COVID-19 inpatients in Wuhan. J Allergy Clin Immunol 10.1016/j.jaci.2020.04.006 (2020).

5. F. Zhou et al., Clinical course and risk factors for mortality of adult inpatients with COVID-19 in Wuhan, China: a retrospective cohort study. Lancet 395, 1054-1062 (2020).

6. T. Novel Coronavirus Pneumonia Emergency Response Epidemiology, [The epidemiological characteristics of an outbreak of 2019 novel coronavirus diseases (COVID-19) in China]. Zhonghua Liu Xing Bing Xue Za Zhi 41, 145-151 (2020).

7. L. e. p. I. s. p. I. S. d. Sanità., Characteristics of COVID-19 patients dying in Italy. Report based on available data on April 6th , 2020.

8. O. o. N. Statistics, The number of deaths involving COVID-19 for females was lower than males in all age groups. (2020).

9. G. Grasselli et al., Baseline Characteristics and Outcomes of 1591 Patients Infected With SARSCoV-2 Admitted to ICUs of the Lombardy Region, Italy. JAMA 10.1001/jama.2020.5394 (2020).

10. I. c. n. a. r. c. (ICNARC), ICNARC report on COVID-19 in critical care 10 April 2020. 5 (2020).

11. A. B. Docherty et al., Features of 20133 UK patients in hospital with covid-19 using the ISARIC WHO Clinical Characterisation Protocol: prospective observational cohort study. BMJ 369, m1985 (2020).

12. E. J. Williamson et al., Factors associated with COVID-19-related death using OpenSAFELY. Nature 584, 430-436 (2020).

13. D. F. Gudbjartsson et al., Spread of SARS-CoV-2 in the Icelandic Population. N Engl J Med 10.1056/NEJMoa2006100 (2020).

14. C. Wenham, J. Smith, R. Morgan, Gender, C.-W. Group, COVID-19: the gendered impacts of the outbreak. Lancet 395, 846-848 (2020).

15. A. Sykes et al., Rhinovirus 16 -induced IFN-alpha and IFN-beta are deficient in bronchoalveolar lavage cells in asthmatic patients. J Allergy Clin Immunol 129, 1506-1514 e1506 (2012).

16. P. A. Wark et al., Asthmatic bronchial epithelial cells have a deficient innate immune response to infection with rhinovirus. J Exp Med 201, 937-947 (2005).

17. S. D. Message et al., Rhinovirus-induced lower respiratory illness is increased in asthma and related to virus load and Th1/2 cytokine and IL-10 production. Proc Natl Acad Sci U S A 105, 13562-13567 (2008).

18. N. G. Papadopoulos, L. A. Stanciu, A. Papi, S. T. Holgate, S. L. Johnston, A defective type 1 response to rhinovirus in atopic asthma. Thorax 57, 328-332 (2002).

19. J. M. Corne et al., Frequency, severity, and duration of rhinovirus infections in asthmatic and non-asthmatic individuals: a longitudinal cohort study. Lancet 359, 831-834 (2002).

20. J. W. Schoggins et al., A diverse range of gene products are effectors of the type I interferon antiviral response. Nature 472, 481-485 (2011).

21. S. N. Waggoner et al., Roles of natural killer cells in antiviral immunity. Curr Opin Virol 16, 15-23 (2016). 
22. A. Nikonova et al., M1-like macrophages are potent producers of anti-viral interferons and M1associated marker-positive lung macrophages are decreased during rhinovirus-induced asthma exacerbations. EBioMedicine 54, 102734 (2020).

23. L. Whitman, H. Zhou, S. Perlman, T. E. Lane, IFN-gamma-mediated suppression of coronavirus replication in glial-committed progenitor cells. Virology 384, 209-215 (2009).

24. L. Malmgaard, Induction and regulation of IFNs during viral infections. J Interferon Cytokine Res 24, 439-454 (2004).

25. L. J. Finney et al., Human Rhinovirus Impairs the Innate Immune Response to Bacteria in Alveolar Macrophages in Chronic Obstructive Pulmonary Disease. Am J Respir Crit Care Med 199, 14961507 (2019).

26. P. Mallia et al., Experimental rhinovirus infection as a human model of chronic obstructive pulmonary disease exacerbation. Am J Respir Crit Care Med 183, 734-742 (2011).

27. A. Singanayagam et al., Corticosteroid suppression of antiviral immunity increases bacterial loads and mucus production in COPD exacerbations. Nat Commun 9, 2229 (2018).

28. A. Singanayagam et al., Antiviral immunity is impaired in COPD patients with frequent exacerbations. Am J Physiol Lung Cell Mol Physiol 317, L893-L903 (2019).

29. R. Thwaites et al., Clinical burden of severe respiratory syncytial virus infection during the first 2 years of life in children born between 2000 and 2011 in Scotland. Eur J Pediatr 179, 791-799 (2020).

30. T. Takahashi et al., Sex differences in immune responses that underlie COVID-19 disease outcomes. Nature 10.1038/s41586-020-2700-3 (2020).

31. M. Contoli et al., Role of deficient type III interferon-lambda production in asthma exacerbations. Nat Med 12, 1023-1026 (2006).

32. N. Yang, H. M. Shen, Targeting the Endocytic Pathway and Autophagy Process as a Novel Therapeutic Strategy in COVID-19. Int J Biol Sci 16, 1724-1731 (2020).

33. E. Andreakos, I. Zanoni, I. E. Galani, Lambda interferons come to light: dual function cytokines mediating antiviral immunity and damage control. Curr Opin Immunol 56, 67-75 (2019).

34. I. E. Galani et al., Interferon-lambda Mediates Non-redundant Front-Line Antiviral Protection against Influenza Virus Infection without Compromising Host Fitness. Immunity 46, 875-890 e876 (2017).

35. M. R. Khaitov et al., Respiratory virus induction of alpha-, beta- and lambda-interferons in bronchial epithelial cells and peripheral blood mononuclear cells. Allergy 64, 375-386 (2009).

36. E. Mantlo, N. Bukreyeva, J. Maruyama, S. Paessler, C. Huang, Antiviral activities of type I interferons to SARS-CoV-2 infection. Antiviral Res 179, 104811 (2020).

37. U. Felgenhauer et al., Inhibition of SARS-CoV-2 by type I and type III interferons. J Biol Chem 10.1074/jbc.AC120.013788 (2020).

38. I. F. Hung et al., Triple combination of interferon beta-1b, lopinavir-ritonavir, and ribavirin in the treatment of patients admitted to hospital with COVID-19: an open-label, randomised, phase 2 trial. Lancet 10.1016/S0140-6736(20)31042-4 (2020).

39. S. Shalhoub, Interferon beta-1b for COVID-19. Lancet 10.1016/S0140-6736(20)31101-6 (2020).

40. V. Gielen, S. L. Johnston, M. R. Edwards, Azithromycin induces anti-viral responses in bronchial epithelial cells. Eur Respir J 36, 646-654 (2010).

41. M. Menzel, H. Akbarshahi, L. Bjermer, L. Uller, Azithromycin induces anti-viral effects in cultured bronchial epithelial cells from COPD patients. Sci Rep 6, 28698 (2016).

42. M. Menzel et al., Azithromycin augments rhinovirus-induced IFNbeta via cytosolic MDA5 in experimental models of asthma exacerbation. Oncotarget 8, 31601-31611 (2017). 
43. J. D. Porter et al., Identification of novel macrolides with antibacterial, anti-inflammatory and type I and III IFN-augmenting activity in airway epithelium. J Antimicrob Chemother 71, 27672781 (2016).

44. F. Touret et al., $<$ em $>$ In vitro $</$ em $>$ screening of a FDA approved chemical library reveals potential inhibitors of SARS-CoV-2 replication. 10.1101/2020.04.03.023846 \%J bioRxiv, 2020.2004.2003.023846 (2020).

45. L. B. Bacharier et al., Early Administration of Azithromycin and Prevention of Severe Lower Respiratory Tract Illnesses in Preschool Children With a History of Such Illnesses: A Randomized Clinical Trial. JAMA 314, 2034-2044 (2015).

46. P. G. Gibson et al., Effect of azithromycin on asthma exacerbations and quality of life in adults with persistent uncontrolled asthma (AMAZES): a randomised, double-blind, placebo-controlled trial. Lancet 390, 659-668 (2017).

47. P. Holt, D. Strickland, A. Custovic, Targeting maternal immune function during pregnancy for asthma prevention in offspring: harnessing the "farm effect"? J Allergy Clin Immunol 10.1016/j.jaci.2020.04.008 (2020).

48. J. P. Collet et al., Effects of an immunostimulating agent on acute exacerbations and hospitalizations in patients with chronic obstructive pulmonary disease. The PARI-IS Study Steering Committee and Research Group. Prevention of Acute Respiratory Infection by an Immunostimulant. Am J Respir Crit Care Med 156, 1719-1724 (1997).

49. B. Orcel, B. Delclaux, M. Baud, J. P. Derenne, Oral immunization with bacterial extracts for protection against acute bronchitis in elderly institutionalized patients with chronic bronchitis. Eur Respir J 7, 446-452 (1994).

50. S. Esposito et al., A randomized, placebo-controlled, double-blinded, single-centre, phase IV trial to assess the efficacy and safety of OM-85 in children suffering from recurrent respiratory tract infections. J Transl Med 17, 284 (2019).

51. I. Iheanacho, Take it like a man: pseudodrugs for man flu. BMJ 342, d2863 (2011).

52. A. Custovic et al., The National Asthma Campaign Manchester Asthma and Allergy Study. Pediatr Allergy Immunol 13, 32-37 (2002).

53. A. Custovic et al., Cytokine Responses to Rhinovirus and Development of Asthma, Allergic Sensitization, and Respiratory Infections during Childhood. Am J Respir Crit Care Med 197, 12651274 (2018).

54. A. Semic-Jusufagic et al., Assessing the association of early life antibiotic prescription with asthma exacerbations, impaired antiviral immunity, and genetic variants in 17q21: a populationbased birth cohort study. Lancet Respir Med 2, 621-630 (2014).

55. Y. Benjamini, Y. Hochberg, Controlling the False Discovery Rate: A Practical and Powerful Approach to Multiple Testing. Journal of the Royal Statistical Society. Series B (Methodological) 57, 289-300 (1995). 
medRxiv preprint doi: https://doi.org/10.1101/2020.09.18.20195784; this version posted September 18, 2020. The copyright holder for this preprint (which was not certified by peer review) is the author/funder, who has granted medRxiv a license to display the preprint in perpetuity.

It is made available under a CC-BY-NC-ND 4.0 International license .

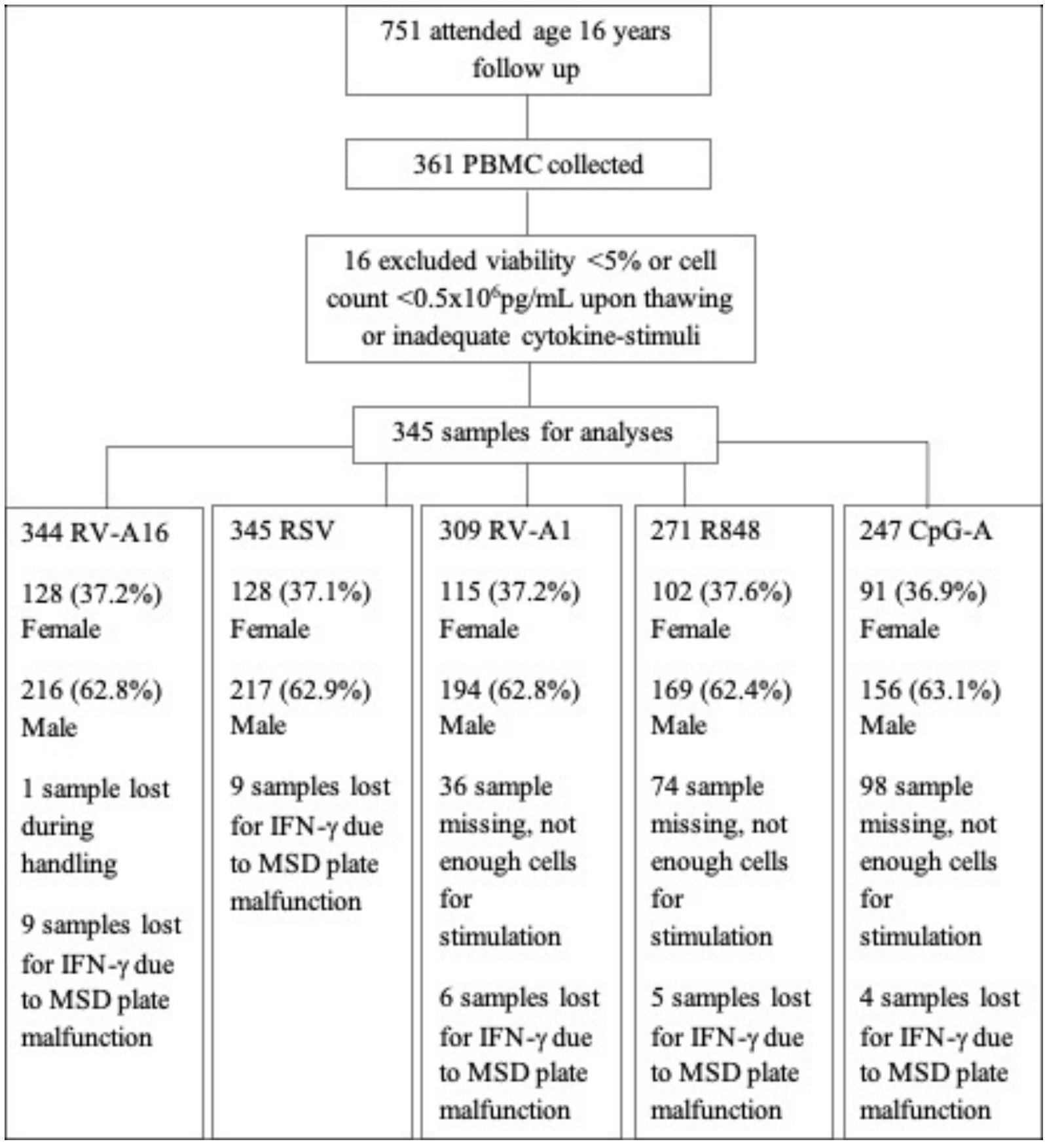

Fig. 1: Participant flow and PBMC stimulation numbers for each stimulus.

503

504 
medRxiv preprint doi: https://doi.org/10.1101/2020.09.18.20195784; this version posted September 18, 2020. The copyright holder for this preprint (which was not certified by peer review) is the author/funder, who has granted medRxiv a license to display the preprint in perpetuity.

It is made available under a CC-BY-NC-ND 4.0 International license .
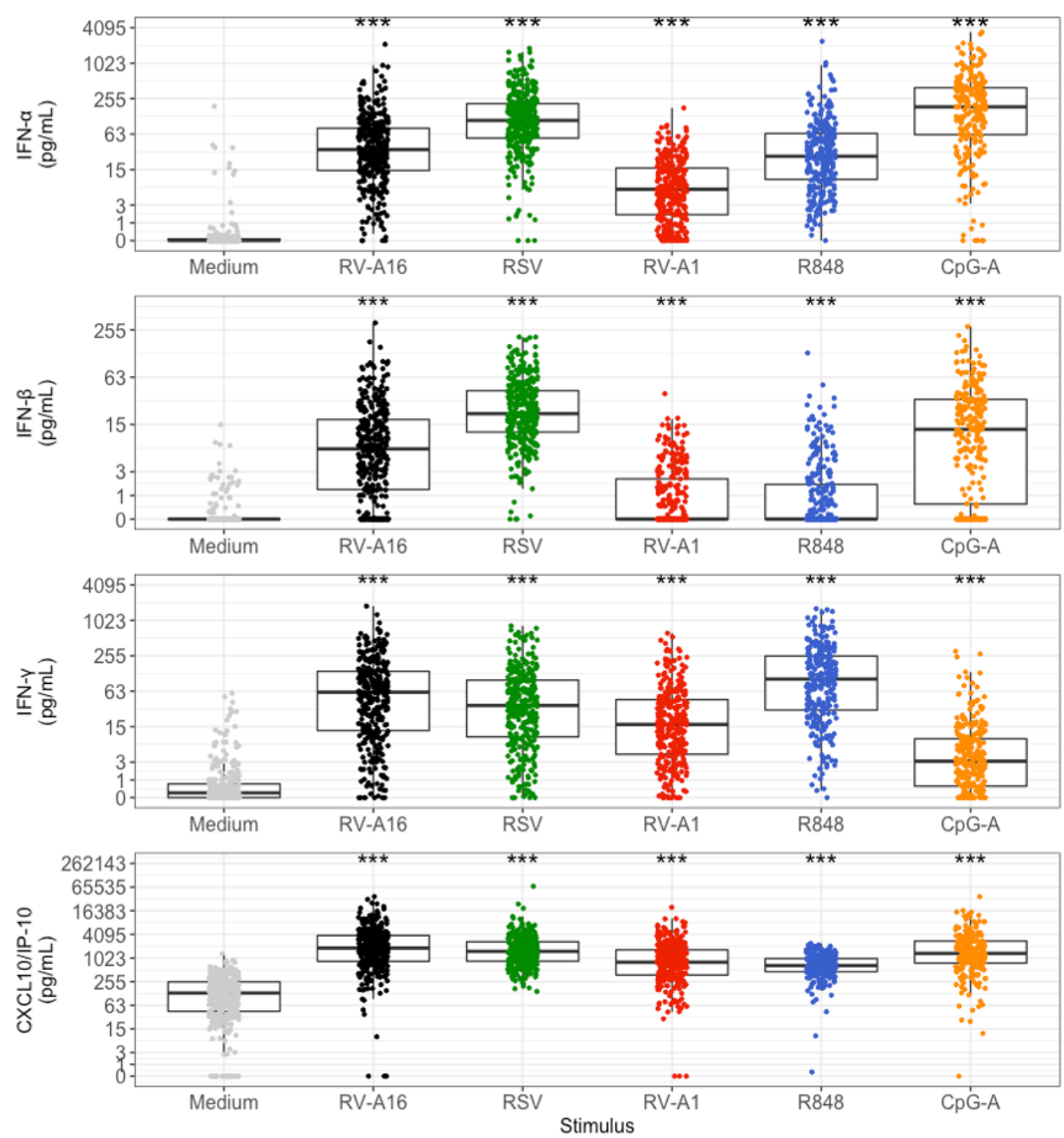

Figure 2. Patterns of PBMC cytokine induction by viral stimuli, compared to medium controls.

507 Data were analysed using Wilcoxon test. Each dot represents an individual participant. Box plots

508 represent the $25^{\text {th }}$ and $75^{\text {th }}$ percentiles, the line the median, with whiskers at the $10^{\text {th }}$ and $90^{\text {th }}$ percentiles.

509 Data are presented in $\mathrm{pg} / \mathrm{mL}$. The y axis is plotted on a logarithmic scale. Significant levels: ${ }^{* *} P<001$

510 compared to medium. 
medRxiv preprint doi: https://doi.org/10.1101/2020.09.18.20195784; this version posted September 18, 2020. The copyright holder for this preprint (which was not certified by peer review) is the author/funder, who has granted medRxiv a license to display the preprint in perpetuity.

It is made available under a CC-BY-NC-ND 4.0 International license .
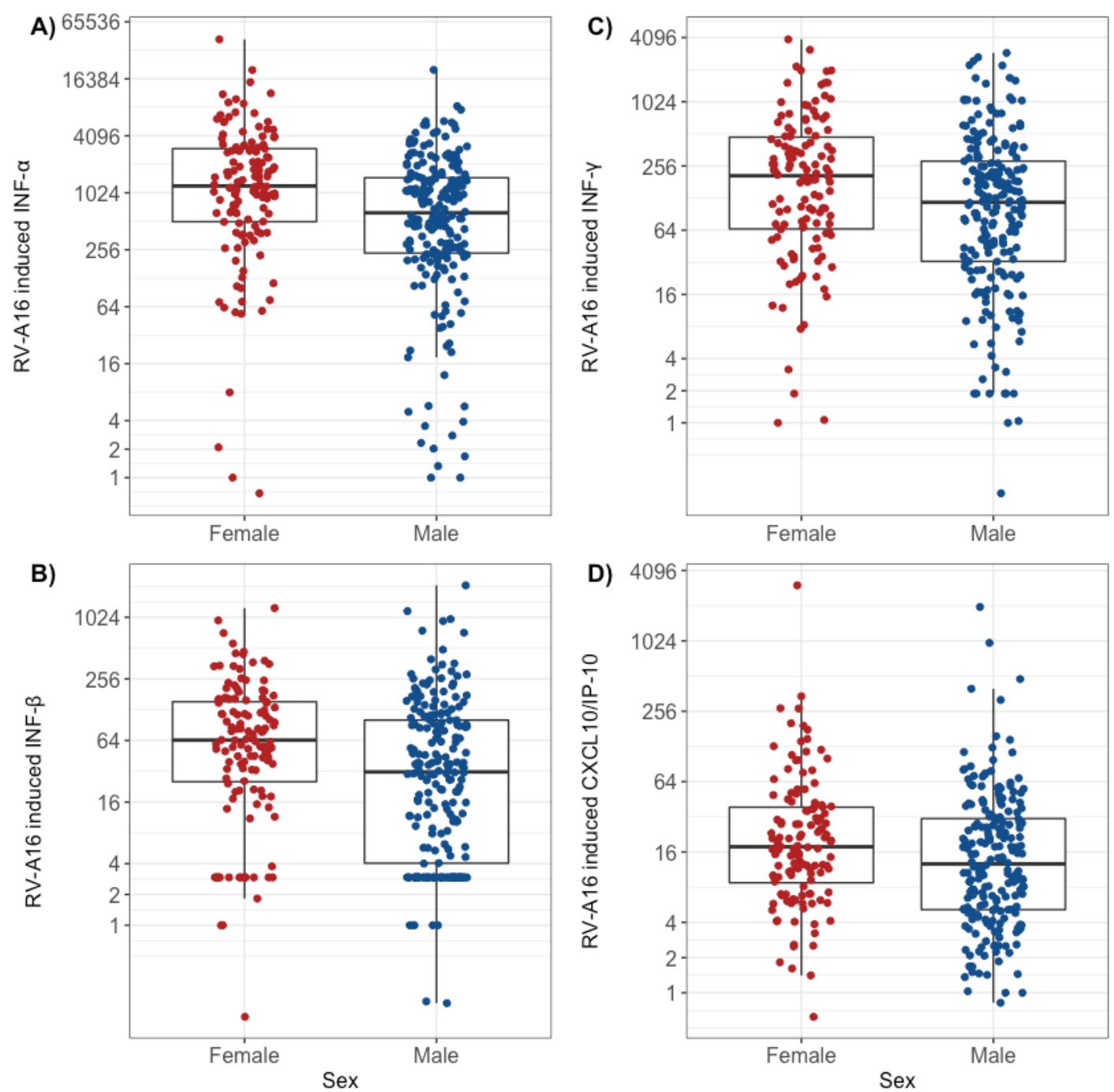

514 CXCL10/IP-10 in response to RV-A16.

515 Box plots represent the $25^{\text {th }}$ and $75^{\text {th }}$ percentiles, the line the median, with whiskers at the $10^{\text {th }}$ and $90^{\text {th }}$

516 percentiles. Each dot represents an individual participant. Wilcoxon test: A) $P<0.001$, B) $P<0.001$, C)

$517 P=0.003$ and D) $P=0.010$. Data are presented as fold induction. The y axis is plotted on a logarithmic scale. 
medRxiv preprint doi: https://doi.org/10.1101/2020.09.18.20195784; this version posted September 18, 2020. The copyright holder for this preprint (which was not certified by peer review) is the author/funder, who has granted medRxiv a license to display the preprint in perpetuity.

It is made available under a CC-BY-NC-ND 4.0 International license .
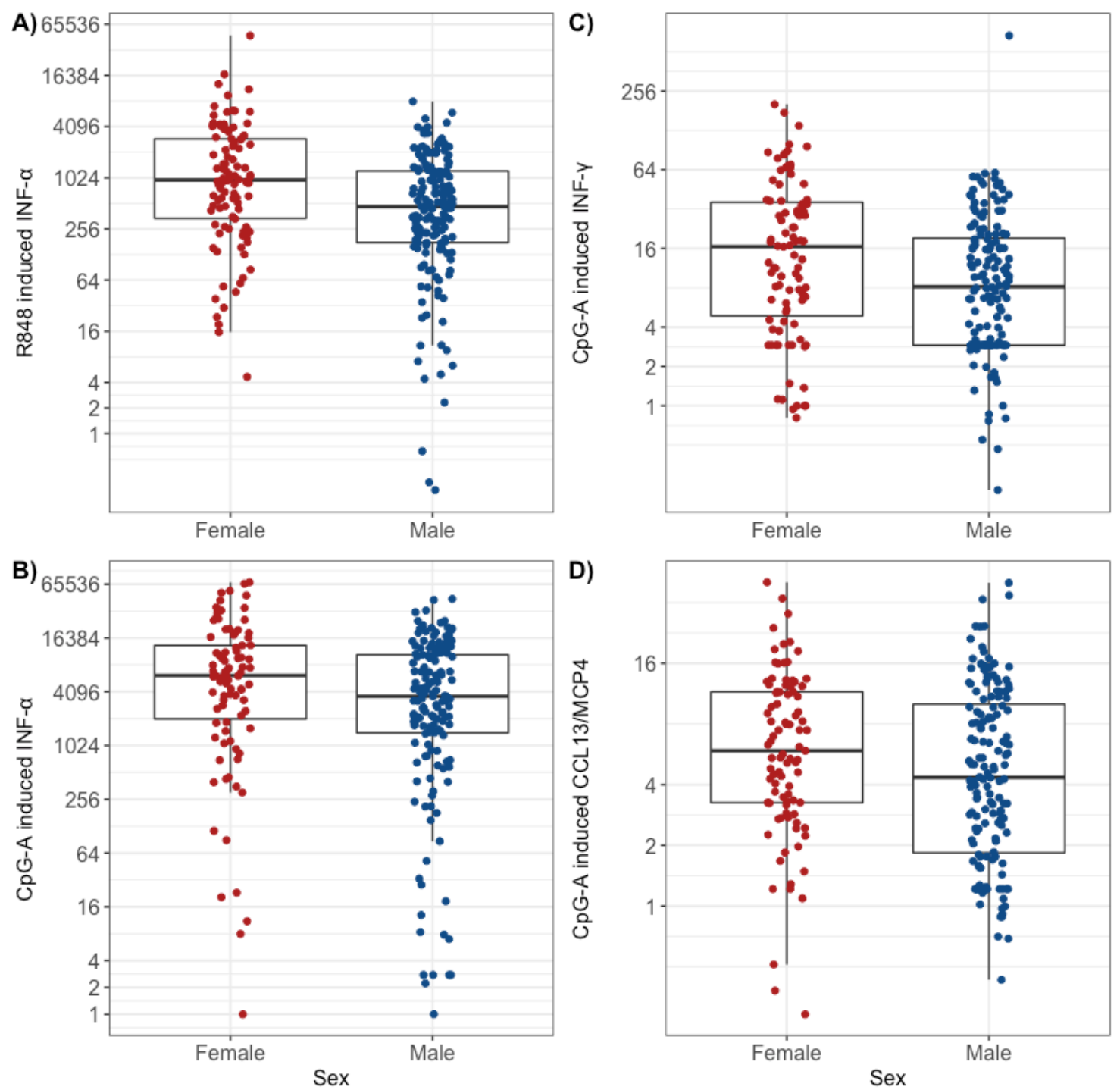

Figure 4: Females have significantly greater induction than males of type I and II IFNs and

521 CCL13/MCP4 in response to the viral mimics R848 and CpG-A.

522 Box plots represent the $25^{\text {th }}$ and $75^{\text {th }}$ percentiles, the line the median, with whiskers at the $10^{\text {th }}$ and $90^{\text {th }}$

523 precentiles. Each dot represents an individual participant. Wilcoxon test: A) $P<0.001$, B) $P=0.015$, C)

$524 P=0.003$ and D) $P=0.040$. Data are presented as fold induction. The y axis is plotted on a logarithmic

525 scale. 
medRxiv preprint doi: https://doi.org/10.1101/2020.09.18.20195784; this version posted September 18, 2020. The copyright holder for this preprint (which was not certified by peer review) is the author/funder, who has granted medRxiv a license to display the preprint in perpetuity.

It is made available under a CC-BY-NC-ND 4.0 International license.

RV-A16 induced INF- $\alpha \mathrm{pg} / \mathrm{mL}$
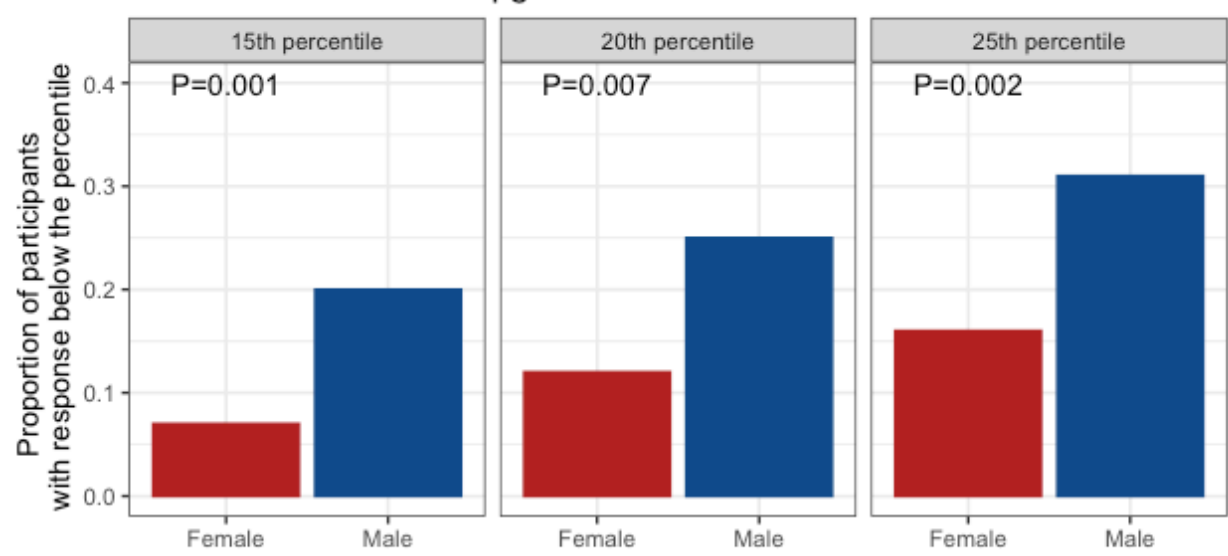

RSV induced INF- $\alpha \mathrm{pg} / \mathrm{mL}$
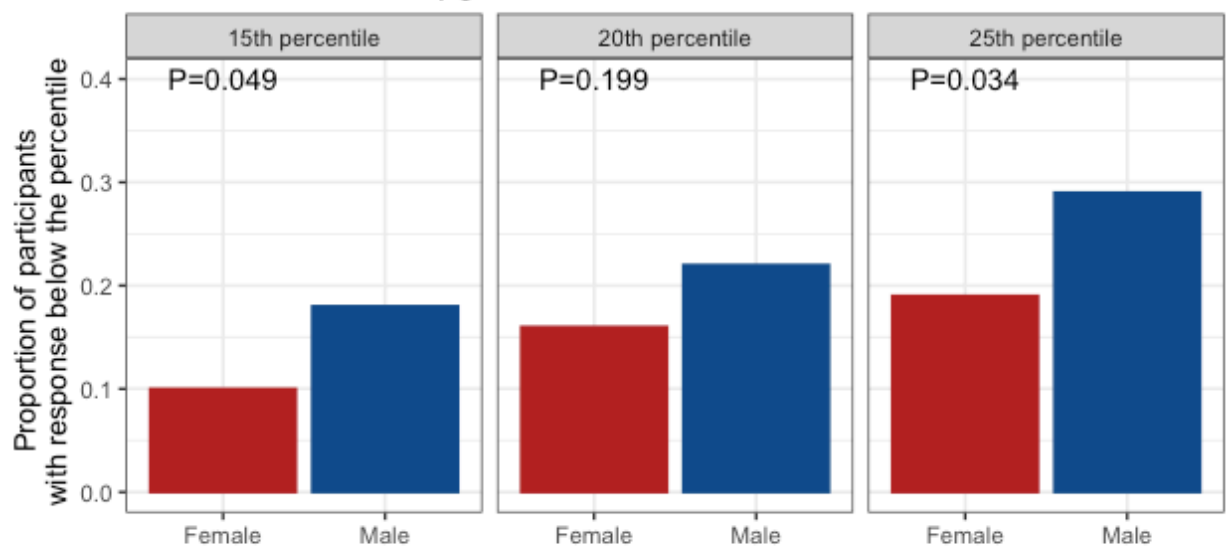

R848 induced INF- $\alpha \mathrm{pg} / \mathrm{mL}$
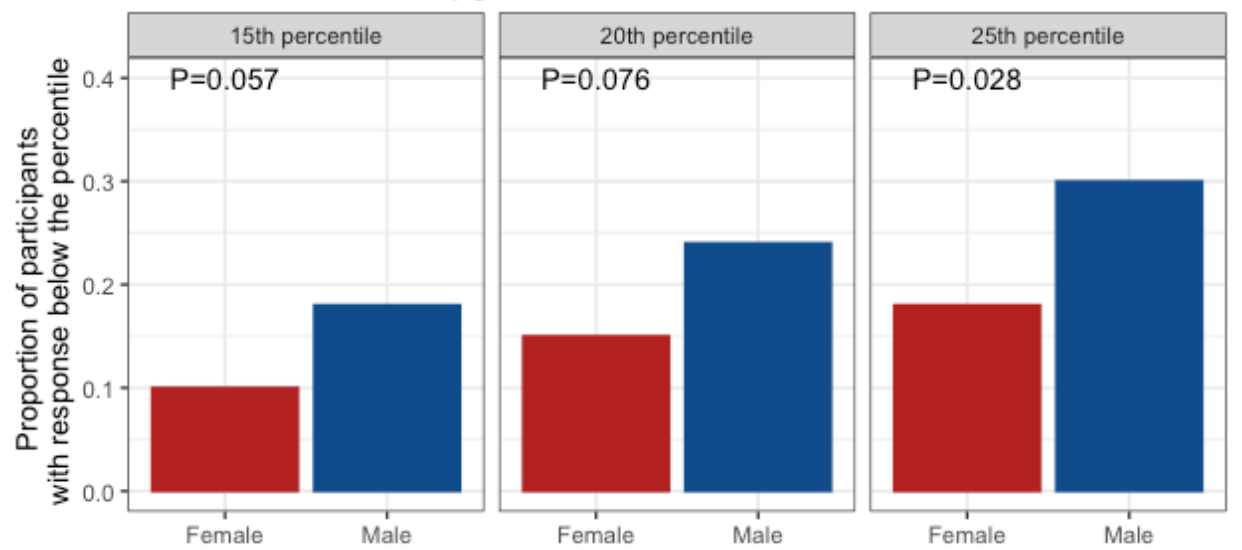

Figure 5: Proportions of males and females with IFN responses to RV-A16, RSV and R848 below

528 the $15^{\text {th }}, 20^{\text {th }}$ and $25^{\text {th }}$ percentiles of the entire population.

$529 P$-values are derived using chi-squared tests. 
medRxiv preprint doi: https://doi.org/10.1101/2020.09.18.20195784; this version posted September 18, 2020. The copyright holder for this preprint (which was not certified by peer review) is the author/funder, who has granted medRxiv a license to display the preprint in perpetuity.

It is made available under a CC-BY-NC-ND 4.0 International license .

530 Table 1: Comparison between sexes of demographic and clinical characteristics of the study 531 population.

532 Some data was lost due to individuals not attending a follow up or skipping the question

\begin{tabular}{|l|ccc|}
\hline \multirow{2}{*}{} & \multicolumn{3}{|c|}{ Cytokine data (n=345) } \\
& Female & Male & p-value \\
& $\mathbf{n}(\%)$ & $\mathbf{n}(\%)$ & $\chi^{2}$ \\
\hline Ethnicity (Caucasian) & $121 / 126(96.0)$ & $204 / 212(96.2)$ & 0.504 \\
\hline Younger siblings & $112 / 217(51.6)$ & $70 / 128(54.7)$ & 0.581 \\
\hline Older siblings & $62 / 128(48.4)$ & $121 / 215(56.3)$ & 0.159 \\
\hline Day care attendance & $91 / 121(75.2)$ & $153 / 209(73.2)$ & 0.690 \\
\hline Maternal smoking (pregnancy) & $9 / 128(7.0)$ & $19 / 212(9.0)$ & 0.530 \\
\hline Maternal smoking (current) & $10 / 126(7.9)$ & $29 / 217(13.4)$ & 0.127 \\
\hline Maternal asthma & $23 / 128(18.0)$ & $39 / 217(18.0)$ & 0.999 \\
\hline Paternal asthma & $22 / 128(17.2)$ & $29 / 217(13.4)$ & 0.334 \\
\hline Dog ownership & $40 / 127(31.5)$ & $80 / 216(37.0)$ & 0.298 \\
\hline Cat ownership & $29 / 127(22.8)$ & $54 / 215(25.1)$ & 0.634 \\
\hline Current asthma & $16.0(0.65)$ & $16.1(0.55)$ & 0.763 \\
\hline Current wheeze & $3.42(0.47)$ & $3.51(0.91)$ & 0.242 \\
\hline Age at follow up & $20 / 126(18.3)$ & $39 / 213(18.3)$ & 0.567 \\
\hline Birth weight (kg) & $18 / 126(14.3)$ & $33 / 215(15.3)$ & 0.790 \\
\hline
\end{tabular}

533 
535 Table 2: Differences between males and females in IFN and IFN-induced chemokine responses to

536 viral stimuli. Data were analysed using the Wilcoxon test. $P$ values and adjusted $P$ values less than 0.05

537 are in bold. The group with the higher IFN and IFN-induced chemokine induction is highlighted in grey.

\begin{tabular}{|c|c|c|c|c|c|c|}
\hline Stimulus & Cytokine & $\begin{array}{l}\text { Median log2 fold } \\
\text { Induction [IQR] }\end{array}$ & $\begin{array}{l}\text { Median log2 fold } \\
\text { Induction [IQR] }\end{array}$ & $\begin{array}{c}\text { Female to } \\
\text { Male ratio in } \\
\text { fold } \\
\text { induction }\end{array}$ & $\begin{array}{c}P \\
\text { value }\end{array}$ & $\begin{array}{c}\text { Adjusted } \\
P \text { value }\end{array}$ \\
\hline \multirow{8}{*}{ RV-A16 } & & $\begin{array}{c}\text { Female, } n=128 \\
(37.2 \%)\end{array}$ & Male, $n=216(62.8 \%)$ & & & \\
\hline & IFN- $\alpha$ & 10.24 [8.98-11.55] & $9.30[7.88-10.53]$ & 1.92 & $<0.001$ & 0.001 \\
\hline & IFN- $\beta$ & $6.01[4.66-7.26]$ & $4.98[2.02-6.66]$ & 2.04 & $<0.001$ & 0.003 \\
\hline & IFN- $\gamma$ & $7.69[6.04-8.90]$ & $6.87[5.03-8.15]$ & 1.77 & 0.003 & 0.017 \\
\hline & CCL4/MIP-1 $\beta$ & $2.13[1.47-3.25]$ & $1.98[0.96-2.98]$ & 1.11 & 0.125 & 0.231 \\
\hline & CXCL10/IP-10 & $4.15[3.13-5.27]$ & $3.66[2.36-4.95]$ & 1.04 & 0.010 & 0.041 \\
\hline & CCL13/MCP4 & $2.60[1.19-3.85]$ & $2.10[0.93-3.41]$ & 1.41 & 0.076 & 0.149 \\
\hline & CCL2/MCP1 & 2.09 [1.09-2.95] & $1.91[0.95-2.92]$ & 1.13 & 0.659 & 0.721 \\
\hline \multirow{8}{*}{ RSV } & & $\begin{array}{c}\text { Female } n=128 \\
(37.1 \%)\end{array}$ & Male $n=217(62.9 \%)$ & & & \\
\hline & IFN- $\alpha$ & $11.66[10.53-12.53]$ & 11.24 [9.91-12.21] & 1.34 & 0.018 & 0.055 \\
\hline & IFN- $\beta$ & $6.89[5.83-7.49]$ & $6.62[5.58-7.71]$ & 1.21 & 0.583 & 0.658 \\
\hline & $\mathrm{IFN}-\gamma$ & 7.08 [5.88-8.14] & $6.54[4.84-8.11]$ & 1.45 & 0.062 & 0.142 \\
\hline & CCL4/MIP-1 $\beta$ & $1.60[1.08-2.36]$ & $1.58[0.98-2.20]$ & 1.01 & 0.380 & 0.475 \\
\hline & CXCL10/IP-10 & $3.67[2.59-4.83]$ & $3.36[2.38-4.62]$ & 1.24 & 0.210 & 0.304 \\
\hline & CCL13/MCP4 & $1.46[0.42-2.51]$ & $1.12[-0.11-2.13]$ & 1.27 & 0.019 & 0.055 \\
\hline & CCL2/MCP1 & $1.75[0.93-2.53]$ & $1.64[0.64-2.65]$ & 1.08 & 0.799 & 0.848 \\
\hline \multirow{8}{*}{ RV-A1 } & & $\begin{array}{c}\text { Female } n=115 \\
(37.2 \%)\end{array}$ & Male $n=194(62.8 \%)$ & & & \\
\hline & IFN- $\alpha$ & 7.54 [5.68-8.92] & $6.91[4.92-8.34]$ & 1.55 & 0.011 & 0.041 \\
\hline & IFN- $\beta$ & $1.21[1.21-3.61]$ & $1.21[1.21-3.16]$ & 1.00 & 0.483 & 0.583 \\
\hline & IFN- $\gamma$ & $6.08[4.32-7.27]$ & $5.51[3.69-6.83]$ & 1.48 & 0.066 & 0.142 \\
\hline & CCL4/MIP-1 $\beta$ & $0.93[0.43-1.41]$ & $0.71[0.20-1.13]$ & 1.16 & 0.010 & 0.041 \\
\hline & CXCL10/IP-10 & $3.05[1.94-4.17]$ & $2.75[1.36-3.85]$ & 1.23 & 0.041 & 0.104 \\
\hline & CCL13/MCP4 & $3.39[2.07-4.47]$ & $2.70[0.67-3.80]$ & 1.61 & 0.002 & 0.017 \\
\hline & CCL2/MCP1 & $2.00[1.09-2.77]$ & $1.84[0.85-2.58]$ & 1.12 & 0.217 & 0.304 \\
\hline \multirow{8}{*}{ R848 } & & $\begin{array}{c}\text { Female } n=102 \\
(37.6 \%)\end{array}$ & Male $n=169(62.4 \%)$ & & & \\
\hline & IFN- $\alpha$ & 9.91 [8.41-11.52] & 8.87 [7.47-10.26] & 2.06 & $<0.001$ & 0.002 \\
\hline & IFN- $\beta$ & $1.53[1.53-3.27]$ & $1.53[1.53-2.84]$ & 1.00 & 0.158 & 0.261 \\
\hline & $\mathrm{IFN}-\gamma$ & $7.51[5.84-9.14]$ & $7.11[5.45-8.60]$ & 1.32 & 0.164 & 0.261 \\
\hline & CCL4/MIP-1 $\beta$ & $3.58[2.94-4.45]$ & $3.46[2.56-4.42]$ & 1.09 & 0.375 & 0.475 \\
\hline & CXCL10/IP-10 & $2.15[1.25-3.15]$ & $1.79[1.04-2.82]$ & 1.28 & 0.069 & 0.142 \\
\hline & CCL13/MCP4 & $0.83[-0.31-1.85]$ & $0.76[-0.85-1.69]$ & 1.05 & 0.239 & 0.322 \\
\hline & CCL2/MCP1 & $2.26[0.79-3.14]$ & $2.02[0.97-3.04]$ & 1.18 & 0.914 & 0.914 \\
\hline \multirow{8}{*}{ CpG-A } & & Female $n=91(36.9 \%)$ & Male $n=156(63.1 \%)$ & & & \\
\hline & IFN- $\alpha$ & $12.6[10.99-13.73]$ & $11.83[10.47-13.38]$ & 1.71 & 0.015 & 0.051 \\
\hline & IFN- $\beta$ & $6.31[2.86-8.10]$ & $5.71[1.40-7.56]$ & 1.52 & 0.155 & 0.261 \\
\hline & $\mathrm{IFN}-\gamma$ & $4.04[2.29-5.17]$ & $3.03[1.54-4.26]$ & 2.01 & 0.003 & 0.017 \\
\hline & CCL4/MIP-1 $\beta$ & $1.35[0.91-1.91]$ & $1.43[0.87-1.81]$ & 0.95 & 0.857 & 0.882 \\
\hline & CXCL10/IP-10 & $4.02[2.94-4.93]$ & $3.66[2.71-4.67]$ & 1.28 & 0.204 & 0.304 \\
\hline & CCL13/MCP4 & $2.56[1.70-3.53]$ & $2.12[0.88-3.32]$ & 1.36 & 0.040 & 0.104 \\
\hline & CCL2/MCP1 & $1.66[1.07-2.19]$ & $1.54[0.89-2.07]$ & 1.09 & 0.528 & 0.616 \\
\hline
\end{tabular}

